\title{
Kebijakan Pupuk, Persepsi dan Implikasi Petani untuk Masa Depan Pembangunan Pertanian
}

\author{
Anto Ariyanto ${ }^{1)}$ \\ ${ }^{1)}$ Staf pengajar Faperta Univ. Lancang Kuning
}

Tulisan ini bersumber dari jurnal Sustainable Agriculture Research; Vol. 1, No. 2; 2012. Judul yang dikritisi berjudul “Assessment of Fertilizer Policy, Farmers' Perceptions and Implications for Future Agricultural Development in Nepal " ditulis oleh Nani Raut \& Bishal K. Sitaula dari Department of International Environment and Development Studies (Noragric), Agricultural University of Norway, Norway yang dipublikasikan pada tahun 2012 oleh Canadian Center of Science and Education.

\section{Pengantar}

Populasi global meningkat dan pertumbuhan ekonomi merupakan kekuatan utama yang mendorong permintaan untuk peningkatan produksi pangan, tanaman produksi dan penggunaan pupuk (Foresight, 2011; FAO, 2011). Boserup (1965) berpendapat bahwa meningkatnya tekanan penduduk berarti bahwa kita harus menemukan cara untuk meningkatkan pasokan makanan melalui peningkatan penggunaan mesin, pupuk, dan lain-lain. Untuk mengatasi peningkatan populasi, kita perlu memanfaatkan teknologi baru dan pergeseran dari praktek pertanian tradisional ke sistem pertanian intensif.

Peran teknologi baru dan inovasi dalam menghadapi tantangan ketahanan pangan secara luas telah diakui. Revolusi Hijau adalah sebuah inovasi diperkenalkan di banyak negara di Asia selama 1960 untuk mencapai swasembada pangan. Subsidi dan kredit program menghasilkan peningkatan penggunaan pupuk di Asia (Gulati \& Sharma, 1995;. Murgai et al, 2001) dan bagian dunia lainnya (Matsumoto \& Yamano, 2011). Dalam konteks ini, intensifikasi pertanian telah dilihat sebagai salah satu pilihan dalam agenda pembangunan negara (Samriddhi, 2011;. Dahal et al, 2009). 
Penelitian yang dilakukan oleh Nani Raut dan Bishal K. Sitaula ini mengkaji perubahan kebijakan pupuk di Nepal selama periode waktu tertentu. Selain itu penelitian ini menilai kesadaran petani dari perubahan kebijakan terhadap subsidi pupuk dan memeriksa persepsi mereka tentang pelayanannya. Selain itu penelitian ini membahas implikasi lingkungan dari kebijakan yang terkonsentrasi pada pupuk kimia, terutama sejauhmana ketahanan pangan pada Negara yang bersangkutan.

\section{Ringkasan}

Yang melatarbelangi penelitian ini, bahwa di Negara Nepal sering terjadi perubahan kebijakan pupuk dalam upaya untuk menjamin pasokan dan untuk mempercepat pertumbuhan produksi pangan melalui penggunaan intensif pupuk kimia. Setelah deregulasi sektor pupuk pada tahun 1999, ada kekhawatiran bahwa pasokan pupuk kimia belum membaik. Pada tahun 2009, pemerintah negara tersebut kembali memperkenalkan subsidi pupuk kimia.

Secara spesifik tujuan penelitian ini adalah sebagai berikut : (1) menentukan asal-usul dan perubahan kebijakan pupuk selama periode waktu; (2) menilai efektivitas pelayanan penyuluhan dan persepsi petani layanan ini; (3) menganalisis implikasi lingkungan dari penerapan peningkatan pupuk kimia pada tanah, dan (4) mempelajari kesadaran petani dari kebijakan subsidi saat ini.

Penelitian ini didasarkan pada survei rumah tangga, diskusi kelompok, lokakarya, review dari literatur yang relevan dan analisis tanah. Kuesioner survei, diskusi kelompok, lokakarya, analisis tanah dan bahan arsip yang digunakan dalam penelitian ini. Perubahan kebijakan pupuk terjadi dalam empat fase yang berbeda, yaitu : (i) tanpa subsidi, (ii) dengan subsidi; (iii) dengan deregulasi perdagangan pupuk; dan (iv) subsidi pupuk saat ini.

Informasi rinci yang diperoleh melalui survey, adalah hal-hal berikut ini, yaitu :1) status layanan dukungan institusional; 2) pandangan petani pada kebijakan subsidi pupuk; 3) keterlibatan petani dalam pelatihan (dan jenis pelatihan yang berkaitan dengan intensifikasi pertanian); 4) informasi para petani sebagai penerima kredit untuk kegiatan pertanian dari pemerintah dan organisasi non-pemerintah, dan 5) tingkat kepuasan petani terhadap kinerja pelayanan penyuluhan dan pelatihan yang ditawarkan.

Data primer dan sekunder mengenai status penggunaan pupuk (sebagaimana tercantum dalam dokumen kebijakan pupuk), dan informasi pada manajemen kesuburan tanah dan 
penyuluhan dikumpulkan dari Divisi Unit Pupuk, Monitoring dan Evaluasi dan Unit Pertanian Moac. Selain itu sampel tanah diambil pada tujuh lokasi yang dipilih dari DAS Ansikhola, untuk mempelajari efek dari intensifikasi.

Analisis kualitatif data dari diskusi lokakarya dan kelompok digunakan selama penelitian. Statistik deskriptif digunakan untuk menganalisis data kuantitatif dan disajikan dalam persentase dalam angka dan tabel. Analisis t-test menggunakan SPSS (versi 16.0) digunakan untuk menganalisis perbedaan $\mathrm{pH}$ tanah pada tingkat signifikansi $\mathrm{p}<0,05$.

\section{Kritikal Jurnal}

Secara umum penelitian ini sebenarnya cukup menarik untuk disimak, peneliti mencoba mendapatkan informasi yang komprehensif terhadap kebijakan pupuk di Negara Nepal dalam upaya menjamin pasokan pupuk dan untuk mempercepat pertumbuhan produksi. Dalam penelitian ini secara spesifik berupaya mendapatkan informasi asal-usul dan perubahan kebijakan pupuk selama beberapa periode waktu, kemudian informasi mengenai efektivitas pelayanan penyuluhan dan persepsi petani terhadap kebijakan tersebut. Selain itu informasi mengenai implikasi lingkungan dari penerapan peningkatan pupuk kimia pada tanah, dan mempelajari kesadaran petani dari kebijakan subsidi saat ini.

Hal yang perlu dikritisi dalam penelitian ini adalah kurangnya landasan teori dan kerangka pikir dalam pelaksanaan penelitian ini. Khususnya teori yang mendukung regulasi subsidi harga pupuk. Subsidi harga sarana produksi bagi masyarakat produsen hasil pertanian bertujuan untuk meningkatkan daya beli petani yang kurang mampu agar dapat membeli sarana produksi dalam jumlah yang cukup untuk meningkatkan atau mempertahankan produktivitas dan pendapatan usahataninya. Dengan harga sarana produksi yang lebih murah, diharapkan masyarakat produsen pertanian juga didorong untuk menerapkan teknologi yang lebih maju sehingga produktivitasnya meningkat. Sementara subsidi harga pangan pangan bagi masyarakat konsumen hasil pertanian bertujuan untuk meringankan beban hidup sekaligus mencukupi kebutuhan pangan pokok minimum dalam rangka penguatan ketahanan pangan masyarakat miskin. 
Secara umum ada`dua jenis subsidi bidang pertanian, yaitu: (1) Subsidi harga sarana produksi ; dan (2) Subsidi harga output (misal komoditi beras). Dampak subsidi dapat dijelaskan secara teoritis sebagai berikut.

\section{Dampak Subsidi Harga Input dan Kenaikan Harga Output}

Dampak subsidi harga sarana produksi pertanian (misalnya pupuk) terhadap produksi pertanian dapat diilustrasikan melalui Gambar 1. Berdasarkan fungsi permintaan pupuk DF, jika harga pupuk (misalnya Urea) tidak disubsidi, yang berarti harga pupuk adalah PF1, maka jumlah permintaan/penggunaan pupuk per ha adalah QF1 dan pada teknologi produksi yang ada yang tercermin pada kurve produksi $\mathrm{Y}=\mathrm{f}(\mathrm{F} ; \mathrm{Z})$, dimana $\mathrm{F}$ adalah pupuk dan $\mathrm{Z}$ adalah input lain, diperoleh produksi per ha sebesar Y1. Jika harga pupuk disubsidi sehingga harga yang dibayar petani turun menjadi PF2 maka penggunaan pupuk per ha akan naik menjadi QF2 dan pada teknologi produksi yang ada akan diperoleh produksi sebesar Y2.

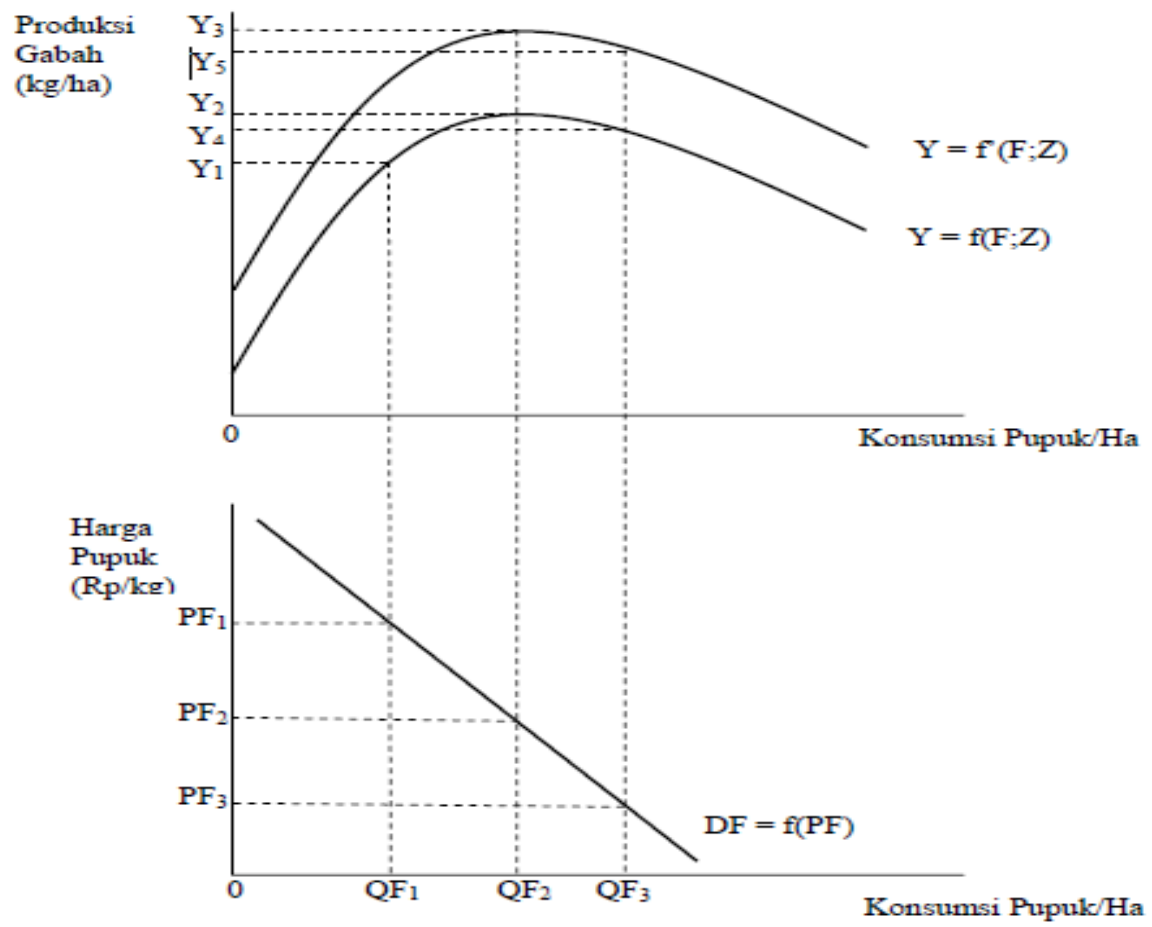

\section{Gambar 1. Dampak Subsidi Harga Pupuk terhadap Jumlah Konsumsi Pupuk dan Produktivitas Pertanian.}


Apabila subsidi harga input dapat mendorong petani untuk menerapkan teknologi yang lebih maju (misalnya penggunaan benih yang lebih unggul lagi) yang tercermin pada kurva produksi $\mathrm{Y}^{\prime}=\mathrm{f}(\mathrm{F} ; \mathrm{Z})$ yang posisinya lebih daripada kurve produksi $\mathrm{Y}=\mathrm{f}(\mathrm{F} ; \mathrm{Z})$, maka dengan penggunaan pupuk yang sama sebesar QF2 produksi dapat dicapai Y3 dimana Y3 > Y1. Jika teknologi tetap tidak berubah tetapi subsidi terlalu besar sehingga harga pupuk yang dibayar petani menjadi sangat murah misalnya PF3, maka produksi malahan akan turun menjadi Y4. Turunnya produksi ini disebabkan sifat produksi pertanian tunduk pada hukum pertambahan hasil yang berkurang (the law of diminishing marginal return), dimana kelebihan penggunaan pupuk akan menyebabkan keracunan pada tanaman yang kemudian berdampak menurunkan produksi.

Pada kondisi dimana produksi per ha sudah berada di bawah titik maksimum karena kelebihan pemakaian pupuk, maka untuk mencapai efisiensi yang lebih tinggi dapat ditempuh dengan 2 alternatif. Alternatif pertama adalah bahwa pada tingkat teknologi yang ada (teknologi tidak berubah), harga subsidi pupuk dinaikkan menjadi PF2 sehingga penggunaan pupuk turun menjadi QF2 dan produksi naik menjadi Y2. Hal ini berdampak meningkatkan efisiensi biaya pupuk, baik bagi petani sebagai pengguna pupuk maupun pemerintah sebagai penyedia anggaran subsidi pupuk. Alternatif kedua adalah pemberian subsidi benih unggul bermutu yang lebih responsif terhadap penggunaan pupuk yang dapat meningkatkan kapasitas produksi tanaman sehingga penggunaan pupuk pada $\mathrm{QF} 3$ akan tetap mampu mencapai tingkat produksi yang lebih tinggi yaitu Y5 pada kurve produksi bergeser ke atas.

Rasio antara harga input terhadap harga output secara teoritis dapat mempengaruhi penggunaan input yang pada akhirnya dapat mempengaruhi produktivitas dan laba usahatani. Penurunan rasio harga, yang berarti harga input menjadi relatif makin murah terhadap harga output, akan mendorong petani menggunakan input lebih banyak yang selanjutnya dapat meningkatkan produksi dan laba usahatani. Sebaliknya, peningkatan rasio harga, yang berarti harga input menjadi relatif makin mahal terhadap harga output, akan mendorong petani menggunakan input lebih sedikit yang selanjutnya dapat menurunkan produksi dan laba usahatani. Hubungan antara rasio harga pupuk terhadap harga gabah dengan dosis penggunaan pupuk dan produksi pada tingkat teknologi yang ada dapat dijelaskan dengan teori efisiensi alokatif (allocative efficiency) melalui Gambar 2. 


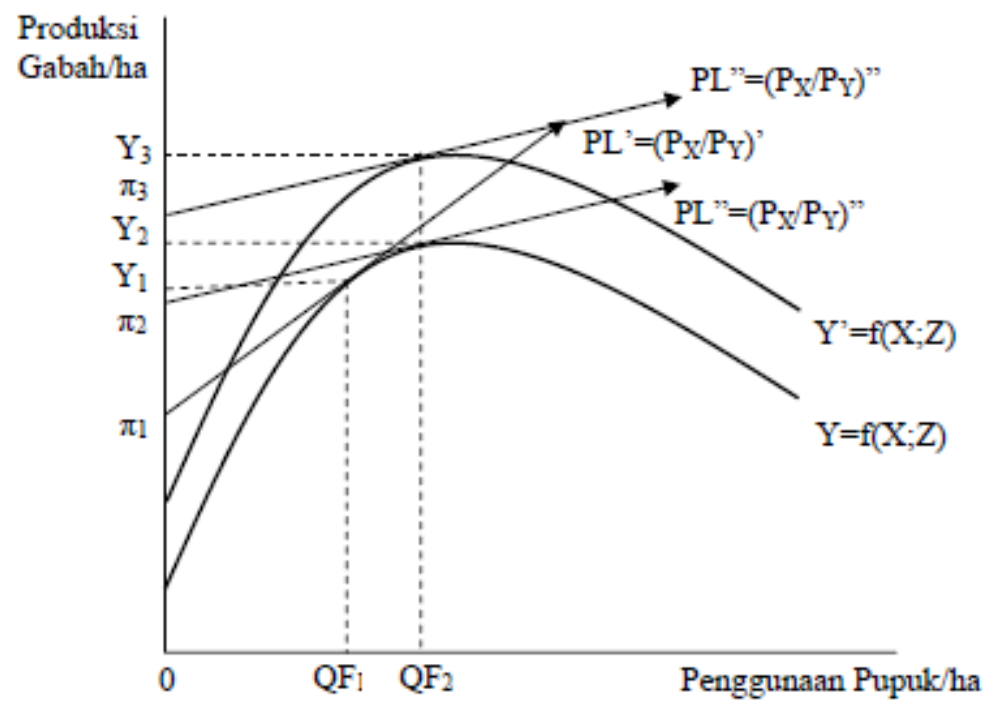

\section{Gambar 2. Hubungan antara Rasio Harga Input-Output dan Penggunaan Input (Pupuk), Produksi dan Laba Usahatani}

Pada tingkat teknologi yang ada, yang tercermin pada kurve produksi $\mathrm{Y}=\mathrm{f}(\mathrm{X} ; \mathrm{Z})$, dengan kondisi dimana rasio antara harga pupuk terhadap harga gabah ditunjukkan oleh kemiringan (slope) garis harga PL' dan petani bersifat rasional secara ekonomi yaitu memaksimumkan laba (profit maximizing), sehingga garis harga $\mathrm{PL}$ ' bersinggungan dengan kurve produksi $\mathrm{Y}=\mathrm{f}(\mathrm{X}$ ' $\mathrm{Z})$, maka jumlah kebutuhan pupuk optimum per hectare adalah sebesar QF1. Pada kondisi ini, produksi optimum yang dapat dicapai adalah Y1 dan laba maksimum adalah $\pi 1$. Karena $\pi 1$ dalam satuan fisik (kg/ha), maka nilai laba maksimum dalam rupiah adalah sebesar $\pi 1$ dikalikan dengan harga jual gabah petani.

Jika rasio harga tersebut menurun, baik karena harga pupuk tetap (akibat HET tetap) dan harga gabah naik (akibat HPP naik), atau karena persentase kenaikan HET lebih kecil dibanding persentase kenaikan HPP gabah, maka garis harga menjadi lebih landai yang ditunjukkan oleh garis PL". Pada kondisi ini, kebutuhan pupuk optimum per hektar meningkat menjadi QF2, yang akan meningkatkan produksi optimum menjadi Y2 dan laba maksiumm menjadi $\pi 2$.

Jika pemerintah hanya memberikan subsidi harga pupuk (bukan gratis, yang berarti petani tetap mengeluarkan biaya untuk membeli pupuk) dan petani bersifat rasional secara ekonomi, yaitu memaksimumkan laba berdasarkan tingkat teknologi yang ada, maka secara 
teoritis mereka tidak ingin mencapai produksi maksimum karena produksi maksimum tidak menyebabkan laba maksimum. Produksi maksimum dapat dicapai hanya apabila harga pupuk bagi petani adalah nol (gratis) sehingga garis harga menjadi datar yang bersinggungan dengan kurva produksi di titik puncaknya.

Solusi terbaik untuk meningkatkan produksi dan laba petani sebenarnya adalah perbaikan teknologi (misalnya penggunaan benih unggul bermutu), yang dapat menggeser kurve produksi keatas menjadi $\mathrm{Y}^{\prime}=\mathrm{f}(\mathrm{X} ; \mathrm{Z})$. Dengan cara ini, penggunaan dosis pupuk yang sama yaitu $\mathrm{QF} 2$ dapat meningkatkan produksi menjadi Y3 dan laba maksimum menjadi $\pi 3$.

Karena itu, upaya penurunan rasio harga input terhadap harga output (melalui persentase peningkatan HPP gabah yang lebih besar dibanding persentase peningkatan HET pupuk) yang dikombinasikan dengan pemberian subsidi harga benih unggul bermutu (dan perbaikan jaringan irigasi) akan memberikan dampak positif lebih besar, baik pada produktivitas maupun laba usahatani padi, dibanding jika hanya mengandalkan instrumen rasio harga pada teknologi yang ada yang mempunyai ruang gerak sangat terbatas (peningkatan produksi hanya terjadi di sepanjang kurve produksi yang ada).

\section{Dampak Subsidi Harga Output}

Bagi kelompok masyarakat konsumen hasil pertanian, dampak subsidi output (misal harga beras) dapat diilustrasikan melalui Gambar 3. Dalam ilustrasi ini, sebuah rumah tangga diasumsikan menggunakan pendapatannya (disposable income) sebesar X hanya untuk membeli 2 macam barang konsumsi yaitu beras dan non-beras. Jika seluruh pendapatan tersebut digunakan hanya untuk membeli beras dengan harga pasar (non subsidi), maka akan mendapatkan beras sejumlah B1, dan jika seluruh pendapatan tersebut digunakan hanya untuk membeli barang non-beras maka akan mendapatkan barang non-beras sebesar A. Garis AB1 yang disebut sebagai garis anggaran (budget line) dan merupakan pembatas anggaran (budget constraint) menunjukkan kombinasi jumlah beras dan non-beras untuk jumlah pendapatan yang sama. Konsumen mempunyai kurva indiferensi (Indifference Curve) IC1, yang menunjukkan tempat kedudukan yang memberikan tingkat kepuasan yang sama bagi konsumen untuk kombinasi jumlah konsumsi beras dan jumlah konsumsi non-beras. Keseimbangan tercapai pada 
titik singgung kurve IC1 dengan garis harga AB1 yaitu E1, yang menunjukkan kombinasi konsumsi barang yang sesuai dengan jumlah pendapatan rumah tangga, yaitu QB1 untuk beras dan QA untuk barang non-beras. Dengan demikian, maka subsidi harga beras bagi konsumen dapat meningkatkan konsumsi beras untuk memenuhi kebutuhan pangan pokok minimum tanpa mengurangi konsumsi non-beras.

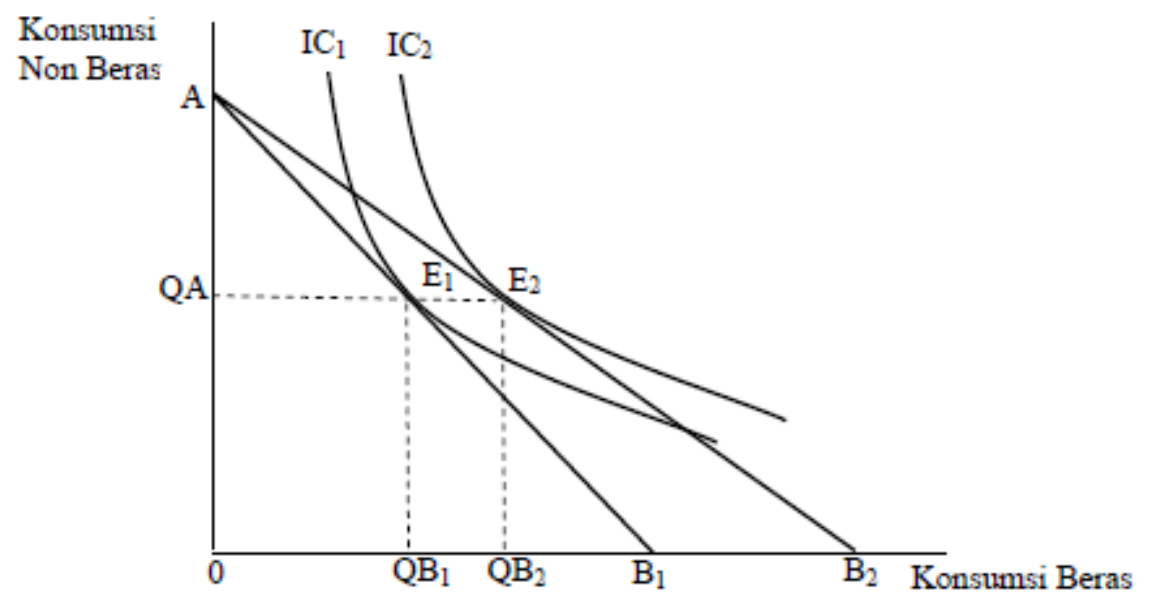

\section{Gambar 3. Dampak Subsidi Harga Beras terhadap Jumlah Konsumsi Beras}

Dunia nyata tidak sederhana seperti yang digambarkan diatas. Jenis pupuk yang digunakan petani tidak hanya satu macam. Demikian pula barang konsumsi non-beras sangat beraneka ragam jenis dan harganya. Namun model yang sederhana tersebut diatas minimal dapat memberikan kemungkinan untuk dapat memahami filosofi kebijakan subsidi harga secara lebih mudah, baik untuk sarana produksi maupun hasil pertanian (gabah/beras).

Meskipun secara teoritis dan kerangka pikir kurang tersentuh, jurnal ini cukup dapat menjadi referensi dalam menggambarkan perkembangan kebijakan pupuk di Negara Nepal. Selain itu informasi yang diperoleh melalui survei rumah tangga, diskusi kelompok, lokakarya, review dari literatur yang relevan dan analisis tanah, cukup membantu menggambarkan informasi yang sesungguhnya dari kebijakan ini secara objektif. 
Hal yang menarik dari penelitian adalah dibuatnya fase-fase perubahan kebijakan yaitu : (i) tanpa subsidi, (ii) dengan subsidi; (iii) dengan deregulasi perdagangan pupuk; dan (iv) kebijakan subsidi pupuk saat ini. Yang dalam hal ini cukup mendapatkan informasi secara komprehensif tentang 1) status layanan dukungan institusional; 2) pandangan petani pada subsidi pupuk; 3) keterlibatan petani dalam pelatihan (dan jenis pelatihan yang berkaitan dengan intensifikasi pertanian); 4) para petani sebagai penerima kredit untuk kegiatan pertanian dari pemerintah dan organisasi non-pemerintah, dan 5) tingkat kepuasan petani terhadap kinerja pelayanan penyuluhan dan pelatihan yang ditawarkan. Selain itu diambilnya sampel tanah. Hal ini cukup menarik karena peneliti ingin melihat secara langsung efek dari intensifikasi yang terjadi.

Analisis data dalam penelitian cukup sederhana, tanpa model dan formula yang rumit,

karena hanya menganalis secara kualitatif dari yang diperoleh dari diskusi lokakarya dan kelompok selama penelitian. Hanya statistik deskriptif yang digunakan dalam menganalisis data kuantitatif dan disajikan dalam persentase dalam angka dan tabel. Sedangkan sampel tanah hanya dilakukan t-test untuk menganalisis perbedaan $\mathrm{pH}$ tanah pada tingkat signifikansi $\mathrm{p}<0,05$.

\section{Implikasi di Indonesia}

Kebijakan perpupukan di Indonesia tidak jauh berbeda dengan kondisi di Nepal. Kentalnya warna politik dalam berbagai kebijakan tampaknya menyulitkan perbaikan sektor potensial perekonomian Indonesia ini. Usulan perbaikan menuju efisiensi, misalnya, sering dijegal dengan dalih perlindungan petani miskin.

Penerapan revolusi hijau di era orde baru tampak menonjol melalui digalakkannya program Bimas berikut Pasca Usaha Tani yang antara lain berisi (1) penggunaan bibit unggul (2) pemupukan (3) pemberantasan hama dan penyakit (4) pengairan, (5) perbaikan dalam cara bercocok tanam. Namun demikian program ini dirasa cukup kaku, kekakuan tersebut tampak melalui keharusan petani untuk menanam tanaman sebagaimana diinstrusikan pemerintah, program Bimas jagung pada tahun 1971 di Yogyakarta menjadi salah satu contohnya (Mubyarto, 1979). Tak hanya itu saja, bahkan mereka para petani yang tanpa segan menolak instruksi pemerintah, bakal segera dilabelkan sebagai “PKI” (Fanslow, 2007). 
Berbagai bentuk "pemaksaan" di atas agaknya dilatarbelakangi oleh keyakinan Orde Baru bahwa kepercayaan rakyat terhadap pemerintah berikut terciptanya stabilitas sosial-politik nasional dapat diwujudkan dengan pemenuhan kebutuhan pangan rakyat (Revrisond Baswir, 2003). Oleh karenanya, pemerintah pun menggalakkan penggunaan teknologi pertanian modern guna mendongkrak produktivitas pangan.

Harus di akui memang, penerapan Panca Usaha Tani mampu meningkatkan hampir seluruh produktivitas subsektor dalam sektor pertanian. Tercatat, komoditas kapas mengalami laju peningkatan produksi hingga $126 \%$ pada tahun 1974, komoditas beras sebesar $6 \%$, sedangkan palawija dan tanaman hortikultura masing-masing mengalami laju peningkatan sebaesar $15 \%$. Bersamaan dengannya penggunaan pupuk kimia, pestisida berikut alat-alat pengolahan padi pun mengalami laju peningkatan signifikan. Pada tahun 1974, penggunaan pupuk kimia mengalami peningkatan sebesar $3 \%$ (339 ribu ton), sedangkan penggunaan pestisida dengan jenis insektisida dan rodentisida masing-masing mengalami peningkatan sebesar 7\% dan 119\% dibandingkan tahun 1972. Begitu pula dalam periode 1973-1974, penggunaan alat pengolahan padi meningkat sebesar $21 \%$ (Mubyarto, 1979).

Sebagaimana kita ketahui, puncak dari berbagai capaian sukses pertaniuan Indonesia di atas adalah terwujudnya swasembada beras pada tahun 1984-1986. Tercatat antara tahun 19801986 laju peningkatan produksi beras Indonesia rata-rata mencapai $7.1 \%$ per tahun. Namun demikian laju peningkatan tersebut tak berlangsung lama, pasca tahun 1986 produksi berangsurangsur turun, dan pada akhir tahun 1988 pemerintah harus dihadapkan pada pilihan sulit untuk melakukan impor beras dalam rangka memenuhi kebutuhan pangan domestik (Booth, 1992).

Di satu sisi, perihal lain yang patut menjadi perhatian dalam penerapan Revolusi Hijau di Indonesia adalah berbagai implikasi yang hadir kemudian akibat digunakannya teknologi pertanian modern terutama pupuk kimia (pabrik) dan pestisida. Goeswono Soepardi (2000) mengatakan bahwa penggunaan pupuk kimia untuk merangsang lahan dalam menghasilkan zat hara secara terus-menerus mengakibatkan terjadinya kejenuhan lahan. Hal tersebut kemudian berdampak pada tak optimalnya kemampuan lahan dalam menghasilkan tanaman pangan. Begitu pula penggunaan pestisida dalam pemberantasan hama factual justru mengakibatkan munculnya berbagai hama yang kian tangguh akibat mutasi yang terjadi dengan senyawa kimia. 
Lebih jauh penelahaan atas revolusi hijau patut dilayangkan pula pada berbagai muatan tersembunyi atau kepentingan terselubung yang terdapat di dalamnya. Sebagaimana di uraikan sebelumnya, pemerintah menyajikan rentetan perihal positif akan penerapannya di tanah air, namun sebagaimana ungkap Mubyarto, penggunaan pupuk kimia, pestisida dan teknologi pertanian modern secara berlebihan sama artinya dengan diperlukannya modal lebih guna membiayainya, dan hal tersebut menyebabkan tak terhindarkannya pinjaman luar negeri (hutang) oleh pemerintah.

Ditilik melalui aspek kepentingan politis, sebagaimana telah diuraikan sebelumnya, bahwa terpenuhinya kebutuhan pangan rakyat merupakan modal bagi pemerntah membangun kepercayaan rakyat. Di satu sisi kepentingan asing pun dapat pula bermain di dalamnya, yakni dengan menjadikan Indonesia menjadi "lumbung pangan" dari berbagai Negara maju yang mendukung penerapan revolusi hijau. Negara maju cenderung berupaya mempertahankan pola hubungan colonial dengan Negara pinggiran, dimana nilai lebih dari Negara-negara pinggiran yang ditempatkan sebagai penghasil komoditas pangan, dapat disedot sedemikian rupa oleh Negara-negara berkuasa dengan corak produksi teknologi modern (setiawan, 1999).

Lebih jauh, berbagai dampak negative dari penerapan revolusi hijau di Indonesia yang hadir kemudian menunjukkan upaya pemerintah dalam membangun pandangan masyarakat bahwa alam merupakan perihal yang bebas dieksploitasi berikut di manipulasi demi kebaikan manusia.

Secara umum perkembangan Kebijakan perpupukan di Indonesia adalah sebagai berikut :

\section{Kondisi Kebijakan Subsidi Pupuk Sebelum Tahun 1999}

Kebijakan pemberian subsidi pupuk telah dilakukan oleh pemerintah sejak tahun 1971. Sejak itu pula beragam kebijakan mengenai subsidi pupuk baik yang tertuang dalam keputusan pemerintah ataupun keputusan menteri keluar. Kebijakan subsidi pupuk didasari dari posisi penting pupuk yang merupakan input penting dalam produksi pertanian dan mendapatkan perhatian khusus dari pemerintah. Subsidi tersebut diberikan langsung melalui mekanisme harga jual pupuk, terutama pada kegiatan usahatani tanaman pangan. Tujuannya adalah agar harga yang beredar di pasar tidak memberatkan petani sehingga petani masih tetap dapat berproduksi (Kariyasa, 2004). Sebelum digulirkannya paket kebijakan pupuk Desember 1998, secara reguler 
(setiap bulan Oktober) pemerintah melakukan penyesuaian Harga Eceran Tertinggi (HET) pupuk (urea).

\section{Kondisi Kebijakan Penghapusan Subsidi Pupuk Tahun 1999 - 2001}

Krisis ekonomi pada tahun 1998 telah mempengaruhi perekonomian Indonesia secara signifikan. Selain itu, utang Indonesia juga semakin meningkat sementara anggaran biaya tidak mampu mencukupi kebutuhan belanja negara. Pemerintah bahkan mengalami defisit anggaran yang begitu besar menunjukkan realisasi APBN dan defisit anggaran yang dialami pemerintah tahun 1999 - 2003. Hal inilah salah satu yang faktor kuat melatarbelakangi dihapuskannya subsidi pupuk.

\section{Kondisi Kebijakan Subsidi Pupuk Setelah Tahun 2001}

Kebijakan subsidi pemerintah yang mulai berlaku pada Agustus 2003 adalah subsidi input produksi pupuk, yaitu gas. Karena gas adalah bahan baku utama dalam memproduksi pupuk. Perubahan pola subsidi ini berarti menjadi subsidi tidak langsung karena subsidi harga gas akan diberikan kepada industri. Ketika subsidi diberikan secara langsung, harga pupuk yang diberlakukan ditingkat petani, masing-masing untuk urea Rp.1.150,00/Kg, pupuk ZA Rp $1.000,00 / \mathrm{Kg}$, TSP Rp 1.500,00/Kg, dan pupuk majemuk Rp 1.750,00/Kg. Dengan subsidi gas maka harga urea turun menjadi Rp 1.050,00/kg, ZA Rp 950,00/kg, TSP Rp 1.400,00/kg, dan pupuk majemuk Rp 1.500,00/kg. Menteri Pertanian RI, Bungaran Saragih mengkalkulasikan bahwa selain menurunkan harga pupuk di tingkat petani, subsidi yang dikeluarkan pemerintah menjadi sangat berkurang. Dengan menghemat anggaran sebesar Rp 350 miliar hingga Rp 500 miliar pada APBN 2003. Namun pada kenyataannya, pengeluaran pemerintah baik dalam besaranya subsidi yang dikeluarkan maupun persentase dalam APBN mulai tahun 2003 justru meningkat dibandingkan dengan tahun sebelumnya yaitu hingga tahun 2002 pada saat menerapkan pola subsidi harga pupuk bukan subsidi gas. Hal ini jelas menunjukan bahwa perhitungan pemerintah belum tepat. Pada tahun 1997 dan 1998 subsidi pupuk memang meningkat tajam, hal ini dipicu oleh adanya krisis ekonomi yang melanda Indonesia.

\section{Kesimpulan}

Meskipun dekade kebijakan pemerintah memprioritaskan pupuk sebagai penggerak utama peningkatan pertanian output, Nepal belum melihat manfaat hasil yang lebih tinggi. Pengembangan efektif dan kebijakan berkaitan dengan distribusi dan penggunaan pupuk selalu 
menjadi tantangan bagi pemerintah. Penelitian ini telah menganalisis usul dan pengembangan kebijakan ini, dan memberikan wawasan dan umpan balik dari petani yang menjadi penerima manfaat calon perubahan kebijakan.

Penelitian ini mencapai kesimpulan berikut:

(1) Meskipun telah ada perubahan dalam skema subsidi pupuk beberapa kali dengan kebijakan subsidi saat ini, impor dan distribusi pupuk kepada petani tetap menjadi tantangan tersendiri.

(2) Petani sering tidak menyadari perubahan kebijakan mengenai pupuk, dari mereka yang menyadari, sebagian besar puas dengan perubahan ini.

(3) Meskipun pemerintah melakukan penyuluhan melalui media, sebagian besar petani menganggap penyuluhan yang diberikan oleh LSM di tingkat lapangan lebih efisien. Perpanjangan tangan pemerintah terhambat oleh kapasitas kelembagaan yang rendah dan ketidakmampuan dari layanan ini untuk beroperasi efektif di lapangan.

(4) Peningkatan keasaman tanah dapat dikaitkan dengan peningkatan penggunaan pupuk nitrogen, dan penurunan hasil bisa membuat sulit untuk memenuhi kebutuhan masa depan untuk makanan. Penelitian lebih lanjut diperlukan jika hasil yang diinginkan harus diperoleh dengan dampak minimal untuk produksi dan lingkungan secara keberlanjutan. Pembangunan pertanian di Nepal harus ditangani dengan tiga pendekatan yaitu : 1) Akses petani ke distribusi pupuk berkualitas yang efisien $\mathrm{k}$ berkualitas harus dipastikan. (2) Perpanjangan layanan harus diperkuat dan harus fokus pada pengelolaan nutrisi tanaman terpadu. (3) Karena sejumlah besar pupuk berasal dari sumber tidak resmi - tiga kali lipat dari impor resmi datang dari agen seperti swasta keterlibatan pedagang dari sektor swasta bisa mengembangkan rasa tanggung jawab di antara pedagang swasta dan meningkatkan mereka partisipasi dalam impor dan distribusi pupuk.

(5) Berdasarkan persepsi petani berkaitan dengan penyuluhan, akan terlihat bahwa akses ke layanan ini diperlukan jika manfaat dari teknik pertanian modern harus ditunjukkan dan adopsi mereka didorong.Oleh karena itu, penyediaan layanan yang efektif penyuluhan sangat penting. 


\section{Referensi}

ACI. (2003). Nepal fertilizer use baseline study. Report of Agrifood Consulting International. Oxford Policy Management, Kathmandu, Nepal.

APP. (1995). Agricultural Perspective Plan (Final Report). National Planning Commission, Agricultural Projects Service Centre, Kathmandu, Nepal.

Blaikie, P. M., \& Sadeque, S. Z. (2000). Policy in high places: Environment and development in the Himalayan Region. International Centre for Integrated Mountain Development, Kathmandu, Nepal.

Boserup, E. (1965). The conditions of agricultural growth: The economics of agrarian change under population pressure. London: Earthscan Publications Ltd.

Brown, S. (1997). Soil fertility, nutrient dynamics, and socio-economic interactions in the Middle Mountains of Nepal. PhD. Thesis, Interdisciplinary Studies in Resource Management Science. University of British Columbia, Vancouver, BC.

Brown, S., \& Shrestha, B. (2000). Market-Driven Land-Use Dynamics in the Middle Mountains of Nepal, Journal of Environmental Management, 59, 217-225. http://dx.doi.org/10.1006/jema.2000.0355

Brown, S., \& Kennedy. G. (2005). A case study of cash cropping in Nepal: Poverty alleviation or inequity? Agriculture and Human Values, 22, 105-116. http://dx.doi.org/10.1007/s10460-004-7234-z

Booth, Anne, at. Al. 1986. Ekonomi Orde Baru, LP3ES

Baswir, Revrisond, 2002, Pembangunan Tanpa Perasaan, Elsam

CIP. (2010). Nepal Agriculture and food security, Country Investment plan.

Dahal, B. M., Nyborg, I., Sitaula, B. K., \& Bajracharya, R. (2009). Agricultural Intensification: Food Insecurity to Income Security in a Mid-Hill Watershed of Nepal. International $\begin{array}{llll}\text { Journal of Agricultural } & \text { Sustainability, } & 7(4), & \text { 249-260. }\end{array}$ http://dx.doi.org/10.3763/ijas.2009.0436

Duc, N. M. (2008). Farmers' satisfaction with aquaculture-A logistic model in Vietnam. Ecological Economics, 68, 525-531. http://dx.doi.org/10.1016/j.ecolecon.2008.05.009

FAO. (2011). Current world fertilizer trends and outlook to 2015. Food and Agriculture Organization of the United Nations, Rome, Italy. 
Foresight. (2011). The future of food and farming: Challenges and choices for global sustainability. Final project report. The Government Office for Science, London.

Ghimire, P. (2009). Distribution of subsidized fertilizer to farmers big challenge. Republica.

Gulati, A., \& Sharma, A. (1995). Subsidy syndrome in Indian Agriculture. Economic and Political Weekly 30: A93-A102.

Guo, J. H., Zhang, Y., Shen, J. L., Han, W. X., \& Zhang, W. F. (2010). Significant acidification in major Chinese croplands. Science, 327, 1008-1010. http://dx.doi.org/10.1126/science.1182570

HMGN. (1997). Fertilizer Control Order. His Majesty’s Government of Nepal.

KC, G. K., Pradhan, D., Upadhyay, B. P., \& Upadhyay, S. (2003). Sharing countries agricultural extension experiences, challenges and opportunities. Regional workshop on operationalizing agriculture extension reform in south Asia, New Delhi, India.

Manandhar, D. N. (2007). Agricultural extension education, Dangol Printers, Kathmandu, Nepal.

Matsumoto, T., \& Yamano, T. (2011). The impacts of fertilizer credit on crop production and income in Ethiopia: In: Emerging Development of Agriculture in East Africa: Markets, Soil and Innovations, T. Yamano et al. Frank (Eds.)

Mubyarto. 1979. Pengantar Ekonomi Pertanian, LP3ES.

Mubyarto, 1981, Teori Ekonomi dan Penerapannya di Asia, Gramesia

MoAC. (2005). Selected indicators of Nepalese agriculture and population. Ministry of Agriculture and Cooperatives, Kathmandu, Nepal.

Murgai, R., Ali, M., \& Byerlee, D. (2001). Productivity growth and sustainability in post-Green Revolution agriculture: the case of the Indian and Pakistan Punjabs. World Bank Research Observer, 16, 199-218. http://dx.doi.org/10.1093/wbro/16.2.199

NARC. (2010). Nepal Agricultural Research Council. NARC's strategic vision for agricultural research 2011-2030. Retrived from http://www.narc.org.np/narc_vision/NARC_vision.pdf

NARMA. (2006). Impact of fertilizer deregulation policy. Prepared by NARMA Consultancy Pvt. Ltd. Kathmandu, for the Ministry of Agriculture and Cooperatives, Kathmandu, Nepal.

NFP. (2002). National Fertilizer Policy. His Majesty’s Government of Nepal. Kathmandu. 
Raut, N., Sitaula, B. K., Aune, J. B., \& Bajracharya, R. M. (2011). Evolution and future direction of intensified agriculture in the central mid-hills of Nepal. International Journal of $\begin{array}{llll}\text { Agricultural Sustainability, } & \text { 9, }\end{array}$ http://dx.doi.org/10.1080/14735903.2011.609648

Raut, N., Dörsch, P., Sitaula, B. K., \& Bakken, L. R. (2012). Soil acidification by intensified crop production in

South Asia results in higher $\mathrm{N} 2 \mathrm{O} /(\mathrm{N} 2+\mathrm{N} 2 \mathrm{O})$ product ratio of denitrification. Soil Biology and Biochemistry, 55, 104-112. http://dx.doi.org/10.1016/j.soilbio.2012.06.011

Rosenau, P. V. (2000). The strengths and weaknesses of public-private policy partnerships. In: Public-Private Policy Partnerships, ed. P.V. Rosenau. Cambridge, Mass: MIT Press.

Setiawan, Bonnie, 1999. Peralihan Kapitalisme di Dunia Ketiga, Pustaka Pelajar.

Samriddhi. (2011). Commercialization of agriculture in Nepal. Discussion Paper. A Samriddhi publication.

Shrestha, R. K. (2010). Fertilizer policy development in Nepal. The Journal of Agriculture and Environment, 11, 126-137.

Thapa, Y. B. (2006). Constraints and approach for improving fertilizer supply for meeting domestic demand. Economic Policy Network, Government of Nepal, Kathmandu, Nepal.

Thapa, G. B., \& Rosegrant, M. W. (1995). Projections and policy implications of food supply and demand in Nepal to the year 2020. Research Report Series, No. 30. Published by Winrock International.

Tiwari, K. R., Nyborg, I. L. P., Sitaula, B. K., \& Paudel, G. S. (2008). Analysis of the sustainability of upland farming systems in the Middle Mountains region of Nepal. International Journal of Agricultural Sustainability, 6(4), 289-306. http://dx.doi.org/10.1007/s10705-009-9289-0 